Techniques \& Culture

\title{
Orientations matérielles de la religion Karinya
}

\author{
Karl-H. Schwerin
}

\section{OpenEdition \\ Journals}

Édition électronique

URL : https://journals.openedition.org/tc/927

DOI : $10.4000 /$ tc. 927

ISSN : 1952-420X

\section{Éditeur}

Éditions de l'EHESS

\section{Édition imprimée}

Date de publication : 1 février 1986

ISSN : 0248-6016

\section{Référence électronique}

Karl-H. Schwerin, « Orientations matérielles de la religion Karinya », Techniques \& Culture [En ligne], 6 | 1986, mis en ligne le 24 janvier 2006, consulté le 29 septembre 2022. URL : http:// journals.openedition.org/tc/927 ; DOI : https://doi.org/10.4000/tc.927

Ce document a été généré automatiquement le 29 septembre 2022.

Tous droits réservés 


\section{Orientations matérielles de la religion Karinya}

Karl-H. Schwerin 